\title{
Christine Ladd-Franklin on the Nature and Unity of the Proposition
}

\author{
Forthcoming in the British Journal for the History of Philosophy \\ Draft - Please cite final version
}

Although in recent years Christine Ladd-Franklin has received recognition for her contributions to logic and psychology, her role in late $19^{\text {th }}$ and early $20^{\text {th }}$ century philosophy, as well as her relationship with American pragmatism, has yet to be fully appreciated. My goal here is to attempt to better understand Ladd-Franklin's place in the pragmatist tradition by drawing attention to her work on the nature and unity of the proposition. The question concerning the unity of the proposition - namely, the problem of how to determine what differentiates a mere collection of terms from a unified and meaningful proposition - received substantial attention in Ladd-Franklin's time, and would continue to interest analytic philosophers well into the $20^{\text {th }}$ century. I argue that Ladd-Franklin had a distinct theory of the proposition and solution to the problem of the unity of the proposition that she developed over the course of her writings on logic and philosophy. In spelling out her views I will also show how her work interacted with that of the pragmatist who was her greatest influence, C.S. Peirce.

I begin in section 1 by presenting a short biographical note on Ladd-Franklin. I then introduce some of Peirce's main views on the nature of the proposition in section 2 . While it may seem a bit odd to begin a discussion of Ladd-Franklin's views with a discussion of Peirce, I begin with Peirce to both introduce the relevant philosophical problems, as well as to better understand Ladd-Franklin's views by presenting the philosophical background that she was working with. In section 3, I will outline the development of Ladd-Franklin's views on the nature of the proposition, up until the point of her contributions to James Baldwin's Dictionary of Philosophy and Psychology. In section 4, I show how, combined with her previous work, Ladd-Franklin's Dictionary entries put 
forth a developed theory of the unity and nature of the proposition. Some of the entries she contributed to the Dictionary were co-authored by Peirce, and it is in their correspondence especially that we can find disagreements and discussions between the two that can help make better sense of Ladd-Franklin's views, and how they differed from Peirce's. Finally, in section 5, I trace some potential lines of mutual influence on Peirce and Ladd-Franklin's views after the turn of the century.

\section{A short biographical note}

Christine Ladd-Franklin (1847-1930) undertook graduate studies at Johns Hopkins University from 1878 until 1882, initially working with, and only being allowed to attend lectures by mathematician James Joseph Sylvester; later she would work with a number of others, most notably Peirce with whom she studied logic. Although later in her career her work would focus primarily on psychology (specifically on theories of vision and color science), while studying with Peirce she made numerous important contributions to logic, most notably the development of the "antilogism", a device she deployed to solve a long-standing problem concerning Aristotelean syllogisms (I say more about this in section 3).

Despite its importance, Ladd-Franklin's work did not nearly receive the attention it deserved, one reason undoubtedly being because she was a woman. Indeed, having anticipated the unfair treatment that she would later receive, she submitted her application to Johns Hopkins under the name of "C. Ladd", which the admissions committee mistook for having been submitted by a man (Hawkins, Pioneer). Although she completed all of her degree requirements for the PhD in 1882, it would not be until 1926 when she was approaching the age of 80 that Johns Hopkins actually awarded her the doctorate. Ahti-Veikko Pietarinen notes that by the time she had eventually been awarded the degree, the Baltimore Sun asked: "Is Johns Hopkins University now 
conferring an honor upon Mrs. Christine Ladd-Franklin, or is Mrs. Christine Ladd-Franklin conferring an honor on Johns Hopkins University?" (Pietarinen, “Christine Ladd-Franklin's and Victoria Welby's correspondence with Charles Peirce", 142).

As several recent commentors have recounted (Agler and Drumus, “Christine LaddFranklin: Pragmatist Feminist”; Janssen-Lauret, “Grandmothers of Analytic Philosophy”), LaddFranklin was also a committed feminist, who undertook a lifelong project of attempting to draw the attention of the philosophical and scientific communities to female scientists and scholars. At the same time, she had to continuously fight to make sure that her own scientific and scholarly discoveries were properly attributed to her: scientists consistently overlooked or ignored LaddFranklin's work, and on a number of occasions claimed her ideas as their own. Unfortunately, much of Ladd-Franklin's work continues to be overlooked to this day. While she has been known as an important American intellectual for some time, it has been only recently that she has been properly considered as a contributor to the development of American pragmatist thought; indeed, while women who contributed to American pragmatism have begun to receive more recognition, the lion's share of attention has been given to a select few, especially Jane Addams and Mary Whiton Calkins. Ladd-Franklin, however, precedes them both, and it is clear from her work in logic and philosophy, as well as her studies with Peirce, that she should be given a place of importance among the early American pragmatists.

While there are many aspects of Ladd-Franklin's logical and philosophical views that deserve attention, here I will focus specifically on her views on the nature and unity of the proposition. This is for two reasons. First, there has not yet been a careful consideration of LaddFranklin's theory of the proposition; and second, given that Ladd-Franklin developed much of her views while working with and in correspondence with Peirce, by looking at her theories on the proposition we can get a better sense of how she fits in the pragmatist tradition. I start, then, with 
an overview of Peirce's view on the nature of the proposition, in order to set the stage for LaddFranklin's.

\section{Peirce's Conception of the Proposition}

Peirce developed his views on the nature of the proposition from his earliest writings up until the point of his death. In his earliest writings the proposition is an entity consisting of three component parts: subject, predicate, and copula, e.g. "The stove is black", where the stove is the subject, blackness is the predicate, and the verb "is" is the copula ("On a New List of Categories" 1868; EP1: $2)^{1}$. According to this early view, the copula has an important role to play in the proposition, as it is the element that connects the subject and the predicate, and thereby unifies the proposition (ibid.). The problem of the unity of the proposition is one that would guide Peirce in his development of his analysis of the proposition, especially later in his writings. The problem can be stated as follows: what differentiates a mere collection of terms from one that constitutes a meaningful proposition? The problem is an old one, tracing its origins back to Plato's Sophist, and was addressed by many early analytic philosophers, including Frege, Russell, and Wittgenstein (see (Bellucci, "Peirce and the Unity of the Proposition") for an overview). Peirce's earliest solution (which he would later reject) is thus one of the simplest: a proposition is unified via the copula, which connects a subject and predicate together into a meaningful whole.

Given the significance that Peirce ascribes to the concept, it is worth asking: what is the nature of the copula? Peirce's early work contains a number of scattered remarks on the question: for instance, in an 1866 manuscript he says that the copula is "a conception without content" whose "function is to conjoin the subject presented with the predicate" (W2: 352). In the abovementioned work from 1868, he states that the copula implies "the conception of being" although again that this

\footnotetext{
${ }^{1}$ In what follows I will follow the standard method of referring to works by Peirce, where EP followed by volume number refers to the Essential Peirce (1991), CP refers to the Collected Papers (1931-66), MS refers to the Manuscripts (1967), and W followed by volume number refers to the Writings (1982).
} 
conception "plainly has no content" (EP1: 2). That the copula is a "conception without content" is perhaps motivated by Peirce's familiarity (and agreement) with Kant's view that existence is not a predicate; thus the copula expresses or implies being, but it does not predicate being. In addition, the notion of "being" implied by the copula "implies an indefinite determinability of the predicate", but does not likewise affect the subject: this is because one can have meaningful propositions in which the subject is indefinite - Peirce's example is "There is a beautiful ellipse" - but not in which the predicate is indeterminate - Peirce's example here is " $A$ has the common character of all things" (“On a New List of Categories" 1867; W2: 49-50).

There is a problem, however, with positing the copula as a distinct element in the proposition alongside a subject and predicate. This is because by positing the copula as an entity which connects the subject and predicate, one is then faced with the additional question of what it is that connects the subject and the predicate to the copula. As Francis Bradley (Bradley, Appearance and Reality) argued, we are then faced with a potential regress when analyzing the nature of the proposition: if there is some other entity that connects the subject to the copula and the copula to the predicate, then we would need to discover yet another entity which connects the subject with that-which-connects-the subject-and-the-copula, etc. Peirce certainly read the work in which Bradley presented his version of the regress (CP 6.500, c. 1906), although that would not be published until twenty years after Peirce's early writings on the proposition.

By the 1880s, however, Peirce's view on the nature of the proposition had changed as a result of the introduction of the notions of index and icon into his semiotic. An index is a sign which "signifies its object solely by virtue of being really connected with it", the paradigmatic example being a "pointing finger", one which "asserts nothing; it only says "There!" It takes hold of our eyes, as it were, and forcibly directs them to a particular object, and there it stops" (W5: 162); while an icon is "a sign which stands for something merely because it resembles it", Peirce's example being a painting that we are unable to distinguish from the real thing which it depicts (W5: 163). The index 
and icon work together to account for the proposition's truth value: the index draws our attention to the world and "purports to be in a real relation to the fact, to be really determined by it" (W5: 255) and the icon is a sign of that which the index is meant to draw our attention to.

In his later discussions the copula that served such an important role in Peirce's early work becomes significantly diminished: indeed, Peirce later discusses the copula as merely a potential unifying symbol, and only when propositions exhibit an "Aryan syntax", namely instances of propositions of the form 'A is B'. However, he notes that the copula cannot serve this role in every proposition, for two reasons: first, there are many different forms of propositions that are not as easily analyzed as 'man is mortal', and second, that there are languages that are structured in such a way as to not involve an explicit copula. Peirce thus shifts his attention from the copula as performing a unifying role to a more general symbol, where the relevant symbol is what allows a proposition to assert something, namely that "two different signs have the same object" (EP2: 20). It is in the mid-to-late 1880s that Peirce emphasizes this notion of assertion in his conception of the proposition, and where we can see the problem of the unity of the proposition expressed differently: the problem of the unity of the proposition can be restated as the problem of determining what it is that allows a collection of terms to assert something.

Like Peirce, Ladd-Franklin would be motivated by the problem of the unity of the proposition, and many of the concepts that Peirce developed will play a role in her own views. As we will see, however, while her views on the nature of the proposition would start by roughly following those of the early Peirce, by the time of their collaboration on entries in Baldwin's Dictionary, the two differed significantly.

\section{Ladd-Franklin's Early Conception of the Proposition}


Ladd-Franklin's earliest work on propositions can be found in her "On the Algebra of Logic", published as part of the 1883 collection of Studies in Logic (edited by Peirce), which was a condensed presentation of some of the work she developed in her dissertation of the same title. In the project she considers the proposition as a unit of logical meaning, and is primarily concerned with developing new symbolic notations, adhering to the view that propositions consist of a subject, copula, and predicate. It is in her 1889 American Journal of Psychology article "On Some Characteristics of Symbolic Logic" in which she considers the nature of the proposition in more detail. Here, like Peirce, she bestows significant importance on the copula, stating that a "proposition has not been stated until the connection between its subject and predicate has been laid down", and is explicit that, "Common logic has long since forced all propositions into the fixed mould, - subject, copula, predicate" (Ladd-Franklin, "On Some Characteristics of Symbolic Logic", 552). In her 1890 Mind article, "Some Proposed Reforms in Common Logic", she develops her views on the proposition further, and considers how different interpretations of the nature of the proposition have consequences for systems of logic:

'All $\mathrm{x}$ is $\mathrm{y}$ ' and 'No non-y is $\mathrm{x}$ ' are propositions which stand to each other in a certain relation. In what terms we shall describe that relation can only be decided after we have fixed upon our definition of proposition. But there are two definitions in common use, and the proposition is a totally different thing according as one or the other of them is adopted. According to one, a proposition is "a portion of discourse in which a predicate is affirmed or denied of a subject"; according to the other, "every portion of knowledge conveyed in language, everything propounded for belief or disbelief," is a proposition. But by the latter definition, the two statements just made about $\mathrm{x}$ and $\mathrm{y}$ are one and the same proposition. As statements of facts, as descriptions of the universe in terms of $\mathrm{x}$ and $\mathrm{y}$, they are identical; each has the effect simply to deny the existence of the combination $x \bar{y}$ [where " $\bar{y}$ " represents the negation of y]. But they do not affirm or deny the same predicate of the same subject, 
and hence, in the other sense of proposition, they are not the same. I conceive that the latter, that is, the material, sense of the word is the more useful and convenient, and that it is better to say that...[they are] different forms of the same proposition, than to say they are different propositions. (Ladd-Franklin, “Some Proposed Reforms in Common Logic”, 76, emphasis in original)

Here, Ladd-Franklin discusses two ways in which one might conceive of the nature of a proposition: first, strictly in terms of the subjects, predicates, and copula of which it is comprised; and second, in terms of the state of the universe that it describes. In the first sense, 'All $x$ is $y$ ' and 'No non-y is $x$ ' are different propositions, since their respective subjects and predicates are different; in the second sense, however, they are the same proposition, as they both describe the same state of the universe in terms of $\mathrm{x}$ and $\mathrm{y}$. As she states in the above passage, Ladd-Franklin's preferred conception is the second: 'All $\mathrm{x}$ is $\mathrm{y}$ ' and 'No non-y is $\mathrm{x}$ ' are the same proposition, just expressed in different forms.

Although this might seem like a relatively minor point, it bears significant fruit throughout Ladd-Franklin's work on logic. For instance, that propositions are equivalent if they describe equivalent states of the world plays a crucial role in her 1901 Science article "The Reduction to Absurdity of the Ordinary Treatment of the Syllogism", in which she presented her solution to a long-standing problem in logic: that of determining what it was about Aristotelian syllogisms (often referred to by their medieval monikers, like Barbara, Celarent, etc.) that made them all valid². Her solution was to rewrite the syllogisms such that they consisted of three inconsistent propositions, what she referred to as an "antilogism", such that "for the usual three statements consisting of two premises and a conclusion one substitutes the equivalent three statements that are together

${ }^{2}$ This solution can be found in several of her earlier works as well, for instance in (Ladd-Franklin, "On the Algebra of Logic"). 
incompatible" (Ladd-Franklin, "The Antilogism”, 532). This allowed her to reduce the entire set of valid syllogisms to a singular form ${ }^{3}$.

Like the early Peirce, we can see that Ladd-Franklin takes a proposition to be comprised of a subject, copula, and predicate, but also that a proposition is characterized by what it says, and not by its form. It would be in Ladd-Franklin's next major published work on the nature of the proposition that she would develop these ideas further, in her contributions to a number of entries in Baldwin's Dictionary4. Her Dictionary entry for "proposition" shows a continued development of her ideas in the form of three major claims: first, that a proposition is a "judgment expressed in words"; second, that the copula has a "double force"; and third, that the proposition requires an element of "asseveration" that, among other things, unifies the proposition. As I will show below, these claims about the proposition represent important developments in Ladd-Franklin's thought, and that while her early views shared many aspects of Peirce's, her more developed claims represent a significant departure, both from Peirce's early views and the views he had developed by the turn of the $20^{\text {th }}$ century.

\section{The Proposition at the Turn of the Century}

To get a better sense of the developments in Ladd-Franklin's view, I will look to some of her correspondence with Peirce. Indeed, the Dictionary entry for "proposition" to which she and Peirce contributed was the focus of a series of letters between Ladd-Franklin and Peirce in 1901 (all of

\footnotetext{
${ }^{3}$ I do not have space here to do justice to Ladd-Franklin's proof in its entirety. Fortunately there are several excellent reconstructions available: for example, Russinoff ("The Syllogism's Final Solution") provides a proof of Ladd-Franklin's solution using modern development in logic, and Janssen-Lauret ("Grandmothers of Analytic Philosophy") provides a thorough explanation of the proof with an emphasis on Ladd-Franklin's innovations in developing logical operators.

${ }^{4}$ Some of these entries were co-authored with Peirce, while others are listed as being co-authored with Baldwin or other editors, although it is unclear how much content the editors themselves contributed.
} 
which can be found in MS L237)5. In these letters Peirce took issue with a number of aspects of Ladd-Franklin's view. It is somewhat odd, given his own interest in the topic, that Peirce's most general concern was with the idea of dedicating an entry to the proposition at all: in his first letter on the matter, from May 1901 with the heading "Criticism of Mrs. Franklin's Article" Peirce asks, "Why make such a fuss over the definition of proposition?" However, in their correspondence Peirce expressed three more specific concerns with Ladd-Franklin's views: first, with regards to the relationship between propositions and judgments; second, the nature and importance of the copula; and third, the importance of the notion of "asservation"6. As I will show next, Peirce's objections concern both Ladd-Franklin's view of the nature of the proposition and the problem of the unity of the proposition.

\subsection{The Relationship Between Propositions and Judgments}

The first line of Ladd-Franklin's Dictionary entry on "proposition" simply states: "A judgment (q.v.) expressed in words" (Baldwin, Dictionary, 361). It is, as Peirce writes in a May 1901 letter, a somewhat unusual way to approach the concept:

I really don't know what justifies your saying that [the proposition] is "usually" defined as a judgment expressed in words. Very strange must have been your line of readings in logic. On the contrary proposition has usually been defined, after Aristotle, as that which is either true or false. A judgment is what a proposition means, especially for those who think that the meaning of a sign lies in something that may be present to the mind.

\footnotetext{
${ }^{5}$ Pietarinen ("Christine Ladd-Franklin's and Victoria Welby's correspondence with Charles Peirce") notes that there are 51 surviving letters between them in total. Transcriptions of the letters that appear in what follows are my own.

${ }^{6}$ Ladd-Franklin will use the term "asservation" fairly consistently throughout her letters and her published work; Peirce will switch between using the terms "asservation", "asseveration", and "assertion", although he treats them as synonymous.
} 
Peirce's concern, then, is that when it comes to propositions and judgments, Ladd-Franklin is putting the concepts in the wrong order: judgments should be defined in terms of propositions, not propositions in terms of judgments.

What, then, is the basis for the claim that a proposition is a judgment expressed in words? Later in the same entry, Ladd-Franklin clarifies the debate as follows:

The difference of view on this subject is probably to be accounted for by the distinction between judgment and proposition, especially when that difference is accounted for genetically by the 'communicative ' or 'declarative ' function of language. The normal psychological process seems to be the formation of judgment by the acceptance of an enlarged (synthetic) whole of mental content, and then the rise of proposition, in words, by analysis and for communication; this in the mind of the speaker. But in the mind of the hearer, to whom the relation expressed in the proposition is new, this procedure is apparently reversed: two more or less familiar terms are given to him in language, joined in a certain relation; and he, by accepting this relation, forms a new judgment. The logician, if he restrict himself to the point of view of the hearer, should deal strictly with propositions and their communication from one mind to another, holding that they are always synthetic; the psychologist, approaching the proposition from the point of view of mental process and meaning, finds that the proposition is always the analytic issue of an earlier judgment. (Ladd-Franklin in Baldwin, Dictionary, 363)

When considering the relationship between a judgment and a proposition, then, which is given priority is dependent upon the view with which one approaches the topic: from the psychologist's perspective, judgments come first, and then a proposition is developed as a means to communicate those judgments to others. From the logician's point of view, however, the proposition is primary, with judgment being defined as a mental operation that involves a proposition. 
As we have seen above, Peirce's view is that of the logician. While Ladd-Franklin here adopts the view of the psychologist, her more substantial disagreements with Peirce concern the component parts of the proposition, and how the proposition was unified.

\subsection{The Nature and Importance of the Copula}

The second main point of disagreement between Peirce and Ladd-Franklin discussed in their correspondence concerns the nature and role of the copula in an analysis of the proposition. As we saw above, in Peirce's early writings the copula played a central role in the analysis and unification of the proposition. However, after the further development of his semiotic, and the notions of the index and icon in particular, the significance of the copula was greatly reduced. In the first subsection of her Dictionary entry on the proposition entitled “The Import of Propositions", LaddFranklin seems to adhere to a view similar to that of the early Peirce, stating the familiar definition of proposition that "must consist of three terms (between which the relation is said to hold)", namely the subject, predicate, and copula (Ladd-Franklin in Baldwin, Dictionary, 362). Here, however, she assigns a special role to the copula, "whose function is to express at once the nature of the connection between them and the asseveration of that connection" (ibid.). The copula, according to Ladd-Franklin, thus has a "double force", playing both the role of conceptual glue between subject and predicate, as well as that which accounts for the assertion of that connection. She provides an example of the proposition "Armies conquer countries", in which we may think of "armies and countries as the objects of consciousness, and of conquer as specifying the nature of the relation and at the same time asserting that it holds" (Ladd-Franklin in Baldwin, Dictionary, 362).

That the copula of a proposition has a double force allows Ladd-Franklin to address two problems at once. The first force of the copula is what we can refer to as the unifying force: what makes a proposition a meaningful whole is that the relevant parts are connected in a certain way, 
and the copula performs that connection. However, we have also seen that Ladd-Franklin does not believe that a proposition is defined solely in terms of its subject, predicate, and copula: again, if it were then "All $\mathrm{x}$ are $\mathrm{y}$ " and "No non-y is $\mathrm{x}$ " would be distinct propositions, which Ladd-Franklin denies. What distinguishes propositions depends on what it asserts; as such, an analysis of the proposition needs to account for this assertion. Here, then, we have the second force of the copula, what we can refer to as the assertive force.

Although Ladd-Franklin's view has its advantages, it is also not without its potential problems. In a May 1901 letter Peirce presents a number of objections to Ladd-Franklin's analysis, focusing on the role she has provided for the copula in the analysis of the proposition. Peirce's worries are threefold. First, he takes issue with Ladd-Franklin's justification for analyzing the proposition in the traditional subject-copula-predicate way. Somewhat curiously, part of LaddFranklin's justification for adhering to the tripartite view is her claim that any proposition can be "inverted", such that the subject and predicate change places, but in which the proposition stays the same: again, she employs the example of the proposition 'A conquers B' which she states can be inverted to 'B is conquered by A'. Peirce, however, is not convinced by this reasoning:

I do not see the force of the argument that because a proposition can be inverted in the English language therefore the analysis of the proposition into two terms and a copula is “justified." In the first place, even in English, I don't know how you invert 'it rains' or 'something is a unicorn.'

Indeed, 'It rains' is an example that Peirce had earlier provided to show that there are propositions that do not explicitly contain a copula, and thus also constitutes a proposition that seemingly cannot be inverted. The proposition 'something is a unicorn' is also potentially problematic for LaddFranklin's view, as it contains an indeterminate subject: as such, inverting it would presumably 
result in a proposition with an indeterminate predicate, which is something that Peirce previously stated was impossible.

However, Ladd-Franklin has a response to these concerns, which can be found in her Dictionary entry:

To discover the three elements involved in A runs, we have again, simply to invert it, One who runs is $A$. And the fact that there is no proposition which cannot be expressed in an exactly equivalent inverted form proves that this analysis of the proposition into two terms and a copulative connecting link is justified. (Ladd-Franklin in Baldwin, Dictionary, 362)

Ladd-Franklin's response to Peirce's concerns, then, seems to be that even in propositions that do have a copula as an explicit component, it is nevertheless contained in the proposition, as is evidenced by the fact that it can be inverted. Again, we see a role for Ladd-Franklin's earlier insight that the same proposition can be expressed in different forms: we might say, then, that since 'A runs' and 'A is one who runs' are the same proposition as they describe the same state of the universe, that even though the former does not contain an explicit copula, it is a way of expressing a proposition that does. What Peirce's challenge is perhaps confusing, then, is the proposition with the form a proposition can take: while it may be true that 'A runs' cannot be inverted, this is merely one possible form of 'A is one who runs', which can.

Peirce's second worry is that the traditional tripartite conception of the proposition fails to account for the ways in which we determine a proposition to be true or false. Peirce outlines his view in another May 1901 letter concerning how the index and icon of a proposition work together to fulfil this role, notions which Ladd-Franklin does not make reference to in her entry:

I note that a sign is something as which brings an object into relation to another sign of the object, its interpretant. Next, signs are one of three kinds of icons, which represents objects only so far as they are like them; indices, which represent objects by blindly forcing a 
relation between the interpretant and the object; and symbols, whose characteristic is that they represent their object upon some general principle represented by the interpretant...A proposition has no force as proposition, that is has no truth or falsity, unless it on the one hand involves a reference to some index which points out what it is talking about, and, on the other hand, involves reference to some icon, which images the sort of thing which it declares the object of that index to be.

As we saw above, Peirce held the view that determining whether a proposition is true or false requires that it has at least some potential connection with the world - what Peirce refers to as a force. While an index and icon can fulfil this function, Peirce's concern is that it is not clear how a combination of subject, copula, and predicate can do so. Hence, Peirce charges, the traditional tripartite view of the proposition cannot account for its force, and thereby cannot account for a proposition's truth value.

Recall, however, that Ladd-Franklin has indeed attempted to account for this force of the proposition in a different way: instead of employing the notions of an index and icon, she instead appeals to the double force of the copula. It is the assertive force that can then account for the truth value of the proposition: the proposition has a truth value in virtue of the fact that the copula not only connects subject and predicate but asserts that the connection holds. The key difference between Peirce's early tripartite view of the proposition and Ladd-Franklin's more developed view, then, comes down to the role of the copula.

By the turn of the century, however, Peirce had become familiar with another problem with the tripartite analysis of the proposition, namely the aforementioned problem expressed by Bradley in 1883. Peirce raises Bradley's worry with regards to Ladd-Franklin's view in a May 1901 letter: 
For if you are, as here, to regard the copula, no longer the mark of asservation, but as the symbol of a separate relation, then on the same principle a new copula would be required to connect this copula with either extreme, and so on ad infinitum.

Again, the worry is that if the copula is an element that unifies the proposition by connecting subject and predicate, we would need to posit another element that connects subject and copula, copula and predicate, and so on. Indeed, Peirce worries that Ladd-Franklin's conception of a copula that has a double-force will only exacerbate this problem:

I should think, on the contrary, that if any conclusion followed, two members were required beside subject and predicate, one to express the nature of the relation, and the other to asservate it.

Peirce questions why Ladd-Franklin assumes that there is one component of the proposition that does two things, rather than two components that do one thing each. If there are two such elements, however, then Bradley's regress problem becomes even more troublesome.

Ladd-Franklin responds to these criticisms in a letter from October 20, 1901:

What is it precisely in such a sentence as "God is", if it is not existence? I take it that in this sentence is is a word of double force, that it stands for is a thing which exists just as in $\underline{\mathrm{He}}$

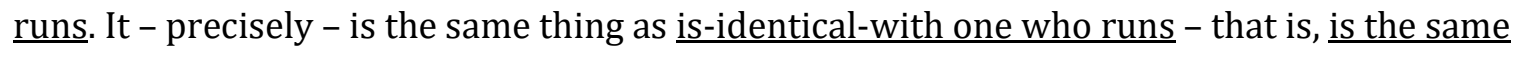
object as and also has the properties of. Or do you not accept my analysis of the import of the proposition...? (emphasis original)

Ladd-Franklin's response to Peirce's challenge, then, is that if we are to consider 'God is' to be a proposition, then since God is the subject, the copula has to be doing double duty as that which expresses something about God - that God exists - and to assert that this is so. There is, after all, 
nothing else in the proposition that can serve those roles, and so both roles must be served by the copula.

In a letter from December 12, 1901, Peirce replies:

God is, logically stated, means something is God. When you have two terms as Some man is good, of course you can invert. For you mean Something is man and good. But when you only have one there is nothing to invert.

A proposition is a sign which separately indicates its object. The subject may be, strictly speaking, a symbol. But it fulfils the function of an index. When you say Some man is good, the term "man" is not, therefore, really the subject or part of the subject but part of the predicate.

Since 'God is' is logically equivalent to 'something is God' according to Peirce, we do not need the copula to perform a double duty; indeed, in the latter form of the proposition, "God" becomes not the subject of whom existence is predicated (something that is impossible, since for Peirce existence is not a predicate), but the predicate, one which predicates of something that it is God (something that is possible, since propositions can have indeterminate subjects). Peirce and Ladd-Franklin's disagreement about how to interpret the subject and predicate, then, impacts what role the copula needs to play in the proposition.

What, then, should we conclude about Ladd-Franklin's proposal that the proposition must contain a copula with a double force? It is not clear that it can avoid Bradley's regress; at the same time, Ladd-Franklin's view is hardly the only one to suffer from this problem. That being said, there are still aspects of the view that call for further explication, especially how it is that a copula might assert that a connection between subject and predicate holds, as well as what this assertion consists in. The nature of assertion is the third and final aspect of the discussion between Peirce and LaddFranklin. 


\subsection{The Importance of "Asservation"}

Although the notion of assertion is something that Peirce addresses in passing throughout many stages of his writing, it would come to occupy a greater part of his attention after the turn of the century, not only with regards to its relationship with the notions of propositions and judgments, but as a topic in its own right. The importance of assertion is already apparent during his correspondence with Ladd-Franklin at the turn of the century: after his above criticism that, by her own argument, Ladd-Franklin ought to distinguish between one component of a proposition that expresses the nature of the relationship between subject and predicate and a separate one which “asservates" it, Peirce asks in a May 1901 letter,

But what does this asservation consist in? Would not an asservation be a proposition without anything outside of it? It seems to be the very first duty of a logician is to analyze asservation and explain what it is.

It is important to note that there is a difference between the kind of assertion that is involved in a proposition and assertion as a speech act. Peirce thought it was imperative to distinguish a proposition from that which can be done with propositions (for instance, we saw above the importance he placed on distinguishing propositions from judgments), and one thing that can be done with a proposition is that it can be asserted. In his January 12, 1902 letter to Ladd-Franklin, Peirce emphasizes this difference between propositions and assertions thereof:

The difference between the assertion of a proposition and the proposition itself is that the one actually performs that act of affixation to the truth which the other only represents. One may write his name on a piece of paper simply to practice his signature; but if one writes it on the back of a promissory note, it is a horse of a different color. So likewise, one may write down a proposition as an aid to the examination of its truth or its structure. But if one 
writes it where it is understood between writer and reader that only the truth is to be written, that is to assert it.

According to Peirce, a proposition, then, does not by itself assert the existence of anything, and thus does not require a sign to make that kind of assertion. When the proposition is asserted by someone, however, there is an assertion of the existence of something; indeed, as Peirce will state in several places throughout his later writings on assertion, asserting a proposition commits one to the proposition asserted, precisely because by asserting it one makes an existence claim (MS 787; MS 284; EP2: 140). However, that the assertion of a proposition makes a claim of existence does not require that there is some component of the proposition which accounts for this claim to existence: instead, it is the circumstances in which the assertion is made which makes and defines the nature of such claims. Hence Peirce's distinction between writing a sentence to practice one's handwriting and writing a sentence to make a promise: in both cases one will write the same proposition, but only in the latter is there an assertion, one which involves a claim to existence (and, thereby, commitment to the truth of what is asserted).

We thus again see a role that Ladd-Franklin attributes to the copula - a symbol that makes an existence claim - is unnecessary according to Peirce: since the proposition itself does not make claims about the existence of anything, there is no need for a component of the proposition to serve this role. However, we have seen above why Ladd-Franklin requires such a symbol, as it is that which accounts for the proposition's truth value. The disagreement between Peirce and LaddFranklin, then, is that while according to Peirce's view a proposition is true or false in virtue of it containing a component that draws our attention to the world, according to Ladd-Franklin's a proposition can be evaluated as true or false on the basis of its claim that something is (or is not).

At this point, then, we are able to get a sense of a more complete picture of Ladd-Franklin's developed conception of the proposition: first, it adheres to a tripartite conception in which a 
proposition contains three elements - subject, copula, and predicate - and is unified in virtue of the copula, which connects the subject and predicate together into a meaningful whole. This, as we have seen, constitutes the first or unifying force of the copula. At the same time, given that the same proposition can be expressed in different forms, the proposition is distinguished by what it asserts, and not by its explicit component parts. As such, the proposition requires some element that accounts for this element of assertion, a role that is again ascribed to the copula. As we have seen, this constitutes the second or assertive force of the proposition. Finally, it is the proposition's double force that accounts for a proposition having a truth value.

Although Ladd-Franklin would continue to have a correspondence with Peirce periodically until 1904, they would not again have the kind of discussion that they did when preparing their Dictionary entries. However, while each came to different conclusions about the nature of the proposition, their respective work after the turn of the century shows marks of mutual influence.

\section{Ladd-Franklin and Peirce on the Proposition after the Dictionary}

After the publication of the second volume of the Dictionary, Peirce's analysis of the proposition developed in ways that are reflective of the three major themes in his correspondence with Ladd-Franklin. For instance, in his 1904 Kaina Stoiceia Peirce emphasizes the differences between a proposition and that which can be done with it:

One and the same proposition may be affirmed, denied, judged, doubted, inwardly inquired into, put as a question, wished, asked for, effectively commanded, taught, or merely expressed, and does not thereby become a different proposition. (MS 517; EP2: 312) 
Again, we see that Peirce is explicit in his opposition to Ladd-Franklin's view that a proposition is a "judgment expressed in words", since for Peirce judging is merely one of many possible activities that one can perform with a proposition.

Peirce also appears to have developed a renewed focus on the nature of assertion as it relates to the nature of the proposition after his work with Ladd-Franklin. Indeed, Peirce's remark to Ladd-Franklin emphasizing the importance of the nature of assertion anticipates a considerable amount of development of the nature of assertion after the turn of the century: for instance, in his 1905 Monist article "What Pragmatism Is" the concept of assertion plays a central role in what Peirce takes the pragmatist mindset to be (Boyd and Heney, "Rascals, Triflers, and Pragmatists"). While it is unknown whether Peirce was specifically motivated to pursue his analysis of assertion as a result of his correspondence with Ladd-Franklin, we can see from the correspondence that the proper analysis of the notion of assertion was on Peirce's mind. Finally, we have also seen that while for Ladd-Franklin the copula was a necessary component of the proposition due to its assertive force, that Peirce is able to account for this aspect of the proposition in a different way means that he no longer has to adhere to the traditional tripartite view. Indeed, his view becomes distinctly bipartite:

A proposition consists of two parts, the predicate which excites something like an image or dream in the mind of the interpreter, and the subject, or subjects, each of which serves to identify something which the predicate represents. ("The Basis of Pragmaticism" 1905: 32, MS 280)

How did Ladd-Franklin's view of the nature of the proposition change after her correspondence with Peirce? It seems that, despite Peirce's objections, she did maintain her view that every proposition required an element to perform the double-duty in unifying and asserting 
the existence or non-existence of something. In her 1912 "Implication and Existence in Logic", for example, she says:

But the true state of things is that every proposition is an existence-proposition, in the sense of being concerned with existence, - that is, of having existence for one of its terms, and that propositions are of two classes according as they are affirmations of existence or denials of existence, - that is, according as they are particular or universal. (Ladd-Franklin, "Implication and Existence in Logic", 652)

Ladd-Franklin does, however, seem to have taken some of Peirce's criticisms to heart, in that she maintains that there are forms of propositions that do not require the copula as an explicit component when a proposition is presented in a certain form:

When there is only one significant term involved, since every proposition is a relation between two terms, the existence term must be present explicitly, as 'some things are accidents,' 'mistakes occur,' ...but in all other cases it is matter of preference whether the existence-term is explicit or implicit. (ibid.)

Despite these smaller conciliations, however, Ladd-Franklin appears to have maintained a consistent conception of the proposition throughout the rest of her writings. Even in light of the differences between their views, Ladd-Franklin would remain a staunch defender of a broadly Peircean conception of logic, especially when it came to opposition from Russell and those supporting the system he developed (for discussion see (Pietarinen, "Christine Ladd-Franklin's and Victoria Welby's correspondence with Charles Peirce") and (Janssen-Lauret, "Grandmothers of Analytic Philosophy"); however, (Trybus, "Two of a Kind") argues that the extent of the opposition from Russell has potentially been overstated, at least in some regards).

Ladd-Franklin did discuss the proposition in later work, although in different ways. For instance, in her 1911 article, "The Foundations of Philosophy: Explicit Primitives" she makes a 
distinction between the roles that different propositions can play within a philosophical system, and the need to make it explicit which propositions are being treated as primitive within the defense of a particular philosophical view, and which are up for debate. This article received a response from Warner Fite, who in his 1912 “Explicit Primitives: A Reply to Mrs. Franklin”, argues that making primitives explicit is impossible, as all parts of a theory hang together in such a way that make it such that no statement truly occupies any more primitive of a position than any other. Interestingly, Fite claims that his views had been particularly well-received by the pragmatists: as the pragmatists generally denied foundationalist assumptions that knowledge had to be grounded by first principles, it might seem natural to say that they should also hold that making these primitives explicit is either impossible or pointless. However, as Ladd-Franklin notes in a response to Fite later that year (Ladd-Franklin, "Explicit Primitives Again") it is incorrect to say that making primitives explicit commits one to a regressive project of defining one's concepts until one hits rock bottom of foundationalist certainty. Instead, Ladd-Franklin defends the very pragmatist line that the primitives in one's theories are ones starting point, and that they are primitive precisely because one cannot define or analyze them further.

\section{Conclusion}

My goal here has been to draw attention to an overlooked part of Ladd-Franklin's views in philosophy and logic. I have argued that her views on the nature of the proposition constitute a well-developed theory, one that is partly guided by an attempt at a solution to the problem of the unity of the proposition. I have also shown how her views, including her unique conception of a copula as possessing a double-force, follows naturally from her other logical and philosophical insights. What I have not done, however, is argued that we should adopt Ladd-Franklin's conception of the proposition, that it is superior to Peirce's, or that she developed the best solution to the 
problem of the unity of the proposition. Rather, my primary goal has been to explicate a more complete view of the nature of the proposition on Ladd-Franklin's behalf, in the hopes that, given her place in the history of American pragmatism, her views on the proposition should themselves be considered pragmatist views, and thus at least a live option that is distinct from those of Peirce and her contemporaries.

\section{Acknowledgements}

This paper has been a lot of different things over the years, and has received a considerable amount of feedback as a result. Thanks to Cheryl Misak, Pierre-Luc Dostie Proulx, and Diana Heney for comments on various versions of the paper, as well as to audience members at the 2017 Eastern meeting of the APA, the 2019 Tilburg-Groningen Workshop on Women in the History of Analytic Philosophy, and the Toronto Pragmatism Reading Group. Thanks also to two referees and the editors of this special collection for their helpful feedback.

\section{Bibliography}

Agler, David W., and Deniz Durmus. “Christine Ladd-Franklin: Pragmatist Feminist.” Transactions of the Charles S. Peirce Society 49 no. 3 (2013): 299-321.

Baldwin, James Mark. Dictionary of Philosophy and Psychology, Vol. 1, 1901, Vol. 2, 1902, Vol. 3, 1905. New York: Macmillan. 
Bellucci, Francesco. "Peirce and the Unity of the Proposition." Transactions of the Charles S. Peirce Society 50 no. 2 (2014): 201-219.

Boyd, Kenneth, and Diana Heney. "Rascals, Triflers, and Pragmatists: Developing a Peircean Account of Assertion." British Journal for the History of Philosophy 25 no. 2 (2017): 287-308.

Bradley, Francis. Appearance and Reality. London: Allen and Unwin, 1893.

Fite, Warner. "Explicit Primitives: A Reply to Mrs. Franklin.” The Journal of Philosophy 9 no. 6 (1912): 155-58.

Hawkins, Hugh. Pioneer: A history of the Johns Hopkins University, 1874-1889. Baltimore: Johns Hopkins University Press, 1960.

Janssen-Lauret, Frederique. “Grandmothers of Analytic Philosophy: The Formal and Philosophical Logic of Christine Ladd-Franklin and Constance Jones." Minnesota Studies in Philosophy of Science 20 (2021): 1-22.

Ladd-Franklin, Christine. “On the Algebra of Logic.” In Studies in Logic by Members of the Johns Hopkins University, edited by Charles Peirce, 17-71. Baltimore: Little, Brown, and Company, 1883.

Ladd-Franklin, Christine. “Richet on Mental Suggestion.” Science 5 no. 106 (1885): 132-4.

Ladd-Franklin, Christine. “On Some Characteristics of Symbolic Logic.” The American Journal of Psychology 2 no. 4 (1889): 543-567.

Ladd-Franklin, Christine. "Some Proposed Reforms in Common Logic.” Mind 15 no. 57 (1890): 7588.

Ladd-Franklin, Christine. “Intuition and Reason.” The Monist 3 no. 2 (1893): 211-19. 
Ladd-Franklin, Christine. "The Reduction to Absurdity of the Ordinary Treatment of the Syllogism." Science 13 no. 328 (1901): 574-6.

Ladd-Franklin, Christine. “The Foundations of Philosophy: Explicit Primitives.” The Journal of Philosophy 8 no. 26 (1911): 708-13.

Ladd-Franklin, Christine. "Implication and Existence in Logic." The Philosophical Review 21 no. 6 (1912): 641-665.

Ladd-Franklin, Christine. "Explicit Primitives Again: A Reply to Professor Fite." The Journal of Philosophy 9 no. 21 (1912): 580-85.

Ladd-Franklin, Christine. "The Antilogism." Mind 37 no. 148 (1928): 532-4.

Peirce, C.S. The Collected Papers of Charles S. Peirce, 8 vols. Edited by C. Hartshorne, P. Weiss, and A.W. Burks. Cambridge: Harvard University Press, 1931-1966.

Peirce, C.S. Writings of Charles S. Peirce: A Chronological Edition, 7 vols. Edited by E. Moore, C.J.W. Kloesel, et al. Bloomington: Indiana University Press., 1982-.

Peirce, C.S. The Essential Peirce: Vol. 2. Edited by Houser, Nathan and Christian Kloesel. Bloomington: Indiana University Press, 1991.

Pietarinen, Ahti-Veikko. “Christine Ladd-Franklin's and Victoria Welby's correspondence with Charles Peirce." Semiotica 196 (2013): 139-161.

Russinoff, I. Susan. “The Syllogism's Final Solution.” The Bulletin of Symbolic Logic 5 no. 4 (1999): 451-469.

Trybus, Adam. "Two of a Kind: Setting the Record Straight on Russell's Exchange with LaddFranklin on Solipsism." Russell - The Journal Of The Bertrand Russell Studies 39 no. 2 (2019): 101-120. 